\title{
Evaluasi Kesesuaian Perairan sebagai Kawasan Budidaya Kappaphycus alvarezii Doty 1985 (Florideophyceae : Solieriaceae), di Kecamatan Jepara
}

\author{
Sarah Pebriyani Turnip*, Ali Djunaedi, Sunaryo \\ Departemen IImu Kelautan, Fakultas Perikanan dan IImu Kelautan, Universitas Diponegoro \\ Jl. Prof. H. Soedarto S.H, Tembalang,Semarang, Jawa Tengah 50275 Indonesia \\ ${ }^{*}$ Corresponding author, e-mail : sarahfernt@gmail.com
}

\begin{abstract}
ABSTRAK: Rumput laut merupakan salah satu komoditas utama dalam budidaya perikanan yang dapat di budidayakan secara masal sehingga dapat dikatakan merupakan komoditas yang strategis. Karakteristik perairan secara fisika dan kimia Perairan Jepara memiliki potensi untuk pengembangan budidaya rumput laut. Namun di Kabupaten Jepara hanya Pantai Karimunjawa yang dimanfaatkan menjadi kawasan budidaya rumput laut. Penelitian ini bertujuan untuk mengetahui tingkat kesesuaian perairan berdasarkan kualitas air untuk kawasan budidaya rumput laut (K. alvarezii) di perairan Kecamatan Jepara yang terkait parameter fisika dan kimia. Penelitian ini merupakan jenis penelitian deskriptif dengan metode survei pengamatan langsung pada bulan Januari-Februari 2021 di 3 lokasi (stasiun) yaitu Pantai Kartini, Pantai Prawean dan Pantai Bandengan. Analisis Kesesuaian perairan menggunakan metode pembobotan (scoring). Hasil evaluasi dari skoring penilaian kesesuaian perairan di Perairan Kecamatan Jepara menunjukkan bahwa Pantai Kartini, Prawean dan Bandengan sesuai untuk dijadikan kawasan budidaya rumput laut (K. alvarezii).
\end{abstract}

Kata kunci: Budidaya rumput laut, Kappaphycus alvarezii, Kesesuaian perairan

\section{Evaluation of the Suitability of Waters as a Seaweed Cultivation Area Kappaphycus alvarezii Doty 1985 (Florideophyceae : Solieriaceae), in Jepara District}

\begin{abstract}
Seaweed is one of the main commodities in aquaculture which can be cultivated en masse so that it can be said to be a strategic commodity. Physical and chemical characteristics of the waters in Jepara waters have the potential for the development of seaweed cultivation. However, in Jepara Regency, only Karimunjawa Beach is used as a seaweed cultivation area. This study aims to determine the level of water suitability based on water quality for the cultivation of seaweed (K. alvarezii) in the waters of Jepara District which are related to physical and chemical parameters. This research is a descriptive type of research with direct survey methods in JanuaryFebruary 2021 in 3 stations, namely Kartini Beach, Prawean Beach and Bandengan Beach. Water suitability analysis uses the scoring method. The results of the evaluation of the assessment of the suitability of waters in the waters of Jepara District show that Kartini, Prawean and Bandengan Beaches are suitable to be used as seaweed cultivation areas (K. alvarezii).
\end{abstract}

Keywords: Cultivation of Seaweed, Kappaphycus alvarezii, Water Suitability

\section{PENDAHULUAN}

Rumput laut merupakan salah satu komoditas utama dalam budidaya perikanan yang dapat dibudidayakan secara massal dan dapat dikatakan merupakan komoditas yang strategis (Dewi dan Ekawaty, 2019). Rumput laut $K$. alvarezii memiliki kandungan karaginan yang banyak dimanfatkaan sebagai bahan utama dalam industri makanan, kosmetik, farmasi dan pupuk organik. Tingginya permintaan akan $K$. alvarezii membuat para pembudidaya dituntut untuk menghasilkan rumput laut dengan cepat, banyak dan berkualitas, sedangkan keberadaan bibit unggul sering bermasalah dan langkanya bibit unggul pada musim-musim tertentu (Erbabley dan Kelabora, 2018). Budidaya rumput laut memiliki peranan penting dalam memenuhi kebutuhan pangan dan gizi, meningkatkan pendapatan, memperluas kesempatan kerja serta menjaga 
kelestarian sumber hayati perairan lainnnya. Faktor fisika kimia perairan menjadi salah satu peranan penting dalam penentuan keberhasilan budidaya rumput laut.

Faktor utama dalam menentukan keberhasilan kegiatan budidaya rumput laut yaitu pemilihan lokasi yang tepat (Dewi dan Ekawaty, 2019). Hal tersebut disebabkan karena produksi dan kualitas rumput laut dipengaruhi faktor-faktor ekologis (oseanografis dan parameter kualitas air). Sebagian besar kegiatan budidaya rumput laut masih banyak ditekuni oleh masyarakat pesisir (Dewi dan Ekawaty, 2019). Perairan Jepara memiliki potensi yang cukup luas dalam mengembangkan budidaya rumput laut, sehingga dapat juga meningkatkan pendapatan masyarakat sekitar. Pantai-pantai di Jepara termasuk kedalam jenis pantai yang landai yang relatif datar dan tidak curam. Perairan Kecamatan Jepara sendiri memiliki banyak pantai yang dapat dijadikan tempat rekreasi dan budidaya. Beberapa pantai di Perairan Kecamatan Jepara, yaitu: Pantai Kartini, Pantai Prawean dan Pantai Bandengan.

Pantai Kartini merupakan pantai yang terdapat aktivitas pelayaran, terdapat aktivitas wisata, berada pada daerah tanjung dan dekat dengan Muara Sungai Kali Wiso. Pantai Prawean termasuk perairan tertutup yang berada di daerah teluk, terdapat muara kecil dan terdapat resort di sekitarnya. Pantai Bandengan termasuk di daerah tanjung yang terdapat aktivitas wisata dan terdapat muara kecil. Namun, masyarakat hanya membudidayakan rumput laut Gracilaria sp. yang hanya dilakukan di tambak-tambak yang tidak produktif lagi dan lebih fokus pada kegiatan pembudidayaan udang vannamei (Fikri et al., 2015). Banyak pantai yang terdapat di Jepara, tetapi hanya Kepulauan Karimunjawa yang memanfaatkan perairannya untuk dijadikan lokasi budidaya rumput laut. Padahal pesisir daratan Jepara memiliki peluang untuk membudidayakan rumput laut. Hal tersebut dapat dilihat dari belum adanya ploting kawasan untuk budidaya rumput laut yang menjadi faktor bahwa potensi budidaya ini belum termanfaatkan secara maksimal.

Penelitian ini bertujuan untuk menganalisis kesesuaian perairan berdasarkan kualitas air sebagai kawasan budidaya rumput laut (Kappaphycus alvarezii) di Perairan Kecamatan Jepara agar dapat dijadikan bahan acuan ataupun meyakinkan masyarakat, pengusaha dan pemerintah daerah dalam pengembangan kegiatan budidaya rumput laut di lokasi tersebut.

\section{MATERI DAN METODE}

Materi yang diamati dalam penelitian ini adalah air laut. Penelitian ini dilaksanakan di perairan Kecamatan Jepara dengan 3 stasiun sebagai kawasan budidaya rumput laut. Pengambilan data dilakukan pada bulan Januari-Februari 2021. Penelitian ini dilakukan dengan menggunakan metode survei yaitu pengamatan langsung di lokasi penelitian. Pengambilan sampel dilakukan pada pagi hari hingga siang hari, yaitu: pada pukul 10.00 sampai $12.00 \mathrm{WIB}$. Frekuensi pengambilan setiap minggu diambil sebanyak 1 kali, sehingga didapatkan 5 kali pengambilan dalam periode 1 bulan.

Penentuan stasiun dipilih dengan menggunakan metode purposive sampling. Penelitian ini dilakukan pada 3 lokasi yang terdapat pada Kecamatan Jepara, yaitu: Pantai Kartini di Desa Bulu (Stasiun 1), Pantai Prawean di Desa Bandengan (Stasiun 2), Pantai Bandengan di Desa Bandengan (Stasiun 3). Secara geografis Pantai Kartini terletak pada 110' 38" 35, $9^{\circ}$ BT 6' $35^{\prime \prime}$ $10,5^{\circ}$ LS, Pantai Prawean terletak pada 110' 39" 7,4 BT 6' $33^{\prime \prime} 46,2^{\circ}$ LS dan Pantai Bandengan terletak pada 110' $39^{\prime \prime} 13,2^{\circ}$ BT 6' $33^{\prime \prime} 7,9^{\circ}$ LS.

Parameter yang diamati secara langsung (in situ), yaitu: suhu, kecerahan, kedalaman, $\mathrm{pH}$, salinitas, DO, kecepatan arus, nitrat fosfat, MPT. Analisis kandungan MPT, nitrat dan fosfat dilakukan di laboratorium dengan mengambil sampel air di lapangan. Mendapatkan kriteria kesesuaian maka dibuat matrik kesesuaian perairan melalui scoring dan faktor pembobot untuk menilai menjadi parameter pembatas kegiatan budidaya rumput laut. Dalam penelitian ini setiap parameter dibagi dalam tiga kelas, yaitu: sesuai, kurang sesuai dan tidak sesuai. Kelas sesuai diberi skor 3 (tiga), kelas cukup sesuai diberi 2 (dua), dan kelas tidak sesuai diberi skor 1 (satu). Parameter yang dapat memberikan pengaruh lebih kuat diberi bobot lebih tinggi (3) dari pada parameter yang lebih lemah (1) pengaruhnya. Matriks kesesuaian (Tabel 1) dan nilai kesesuaian lahan (Tabel 2). Hasil scoring dan pembobotan di evaluasi sehingga didapatkan kriteria kesesuaian yang menggambarkan tingkat kecocokan dari suatu bidang untuk penggunaan tertentu. Interval kelas nilai kesesuaian ditentukan dengan menggunakan rumus menurut Neksidin et al. (2013). 
Journal of Marine Research Vol 10, No.3 Agustus 2021, pp. 369-376

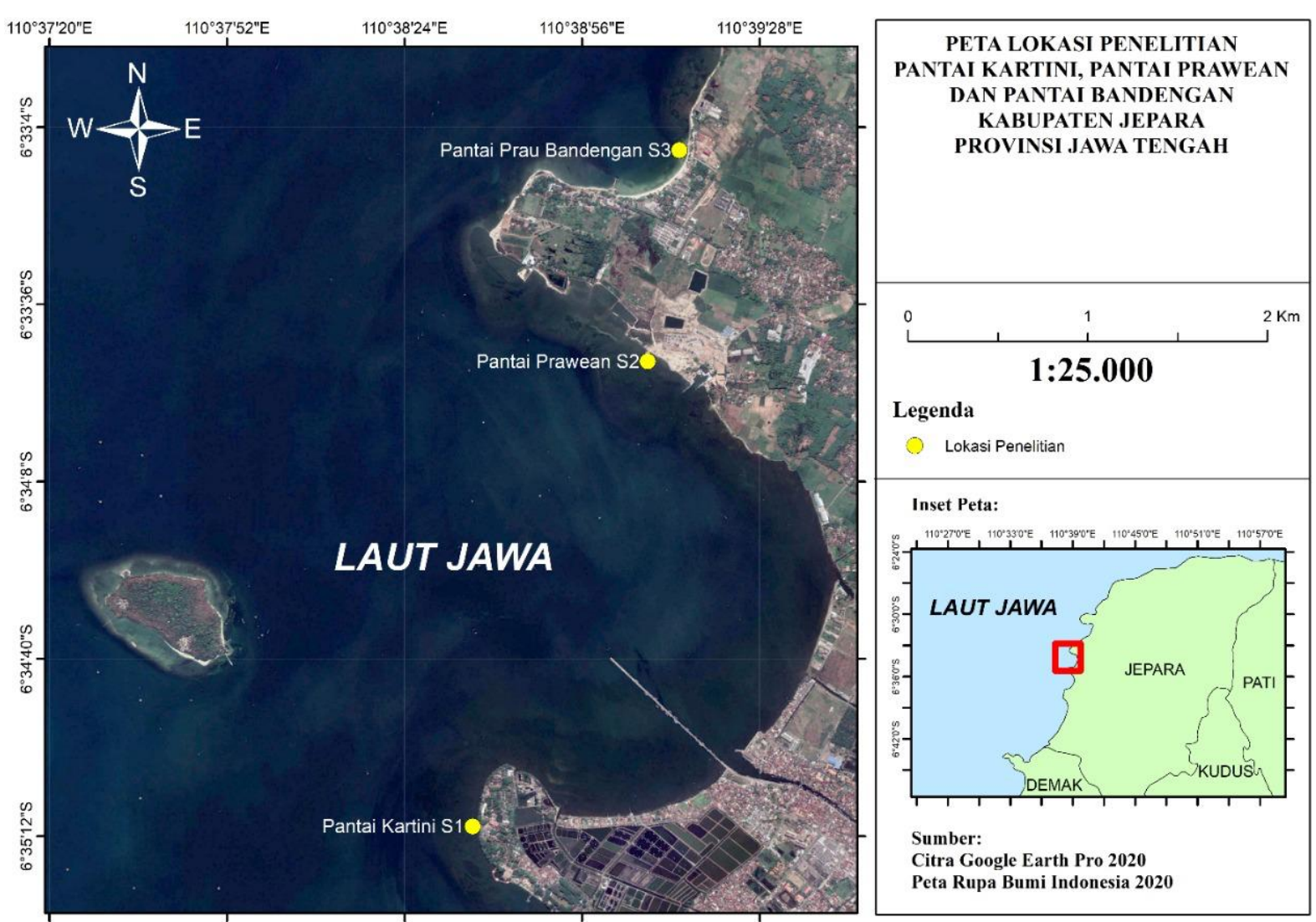

Gambar 1. Stasiun Pengamatan di Perairan Kecamatan Jepara

\section{HASIL DAN PEMBAHASAN}

Nilai parameter kesesuaian di Perairan Kecamatan Jepara dapat dikatakan masuk ke dalam kategori sesuai untuk budidaya rumput laut yang dapat dilihat dari tabel matriks kesesuaian lokasi budidaya rumput laut (Tabel 3). Parameter yang diuji berjumlah 10 parameter dan hanya 7 sampai 6 parameter dari semua stasiun yang sesuai untuk lokasi budidaya rumput laut. Parameter tersebut terdiri dari suhu, kedalaman, $\mathrm{pH}$, DO, MPT, nitrat dan fosfat. Kriteria kesesuaian lahan untuk budidaya rumput laut dapat dilihat pada Tabel 1.

Pengukuran kecerahan di Perairan Kecamatan Jepara pada stasiun 1,2 dan 3 berturut-turut adalah $1,11 \mathrm{~m} ; 1,12 \mathrm{~m}$ dan 1,03 m. Kecerahan pada stasiun 1,2 dan 3 masih dapat dikatakan tergolong baik untuk membudidaya rumput laut (Dewanto et al., 2015). Rendahnya nilai kecerahan pada stasiun 3 dikarenakan saat pengambilan data dilapangan sedang mengalami musim hujan dan perairan di Pantai Bandengan (S3) lebih keruh. Menurut Atmanisa et al. (2020), mengatakan bahwa kecerahan perairan baik lebih dari 1 meter untuk menunjang proses fotosintesis. Nilai kecerahan dapat dipengaruhi oleh keadaan cuaca, waktu pengukuran dan kekeruhan. Kecerahan yang minim akibat kekeruhan dapat disebabkan oleh bahan padatan tersuspensi berupa bahanbahan koloid, lumpur dan partikel organik lainnya. Hal tersebut juga dapat disebabkan oleh gelombang dan arus yang dapat membawa material dari daratan yang dapat menyebabkan kekeruhan (Patty et al., 2020).

Kedalaman pada stasiun 1,2 dan 3 berturut-turut adalah $1,23 \mathrm{~m} ; 1,19 \mathrm{~m}$ dan 1,21 m. Kedalaman pada semua stasiun masuk kategori sesuai. Namun tidak begitu dalam dikarenakan permukaan pantainya relatif landai sehingga kedalaman perairan di lokasi budidaya rumput laut tidak terlalu dalam. Menurut Nugraha et al. (2015), mengatakan bahwa kemiringan pantai yang landai dapat di temui di perairan pantai utara Jawa. 
Arus pada stasiun 1,2 dan 3 berturut-turut adalah 0,$15 ; 0,10$ dan $0,23 \mathrm{~m} /$ det. Arus paling kuat pada stasiun 3 dan yang paling lemah pada stasiun 2. Kecepatan arus pada setiap stasiun di perairan Kecamatan Jepara tidak begitu kuat dapat dikarenakan memiliki topografi yang landai sehingga membuat ombak relatif kecil dan arus yang lemah (Agustang et al., 2019). Kecepatan arus pada stasiun 3 lebih tinggi dapat disebabkan oleh tidak adanya pulau yang menutupi. Menurut Nuning (2015), arus dan gelombang cenderung rendah bila ada pulau yang melindungi area tersebut. Arah arus yang didapatkan pada Pantai Kartini dominan bergerak kearah Barat dan Timur Laut, Pantai Prawean bergerak kearah Barat dan Tenggara sedangkan Pantai Prawean bergerak kearah Barat dan Timur Laut. Menurut Yusuf et al. (2012), arus laut yang mengalir dari Barat ke Timur dikenal dengan musim Barat yang dapat dicirikan dengan kondisi angin kencang, curah hujan yang tinggi, gelombang besar dan kadar garam yang relatif rendah. Menurut Aziz et al. (2019), perairan dekat pantai pola arus cenderung bervarisi karena pengaruh dari morfologi pantai. Pola arus yang tidak merata dapat dikarenakan oleh gaya gesek pada dasar laut dan arus bergerak secara dinamis.

Suhu pada stasiun 1,2 dan 3 berturut-turut adalah 27,$72 ; 28,16$ dan $28,72^{\circ} \mathrm{C}$. Suhu yang paling tinggi berada pada stasiun 3 dan yang paling rendah yaitu pada stasiun 1 (Kartini). Adanya perbedaan suhu pada setiap stasiun dapat disebabkan oleh kedalaman yang berbeda, cuaca yang tidak menentu dan rata-rata cuacanya hujan dan mendung. Menurut Runtuboi et al. (2014), menyatakan bahwa suhu optimal untuk budidaya rumput laut yaitu berkisar $26-33^{\circ} \mathrm{C}$.

Tabel 1. Kriteria Kesesuaian Lahan untuk Budidaya Rumput Laut

\begin{tabular}{|c|c|c|c|c|c|}
\hline No. & Kriteria & Kelas & Skor & Bobot & Sumber \\
\hline 1. & Kecerahan (m) & $\begin{array}{l}>3 \\
1-3 \\
<1\end{array}$ & $\begin{array}{l}3 \\
2 \\
1\end{array}$ & 3 & Radiartha et al (2005) \\
\hline 2. & Nitrat (mg/L) & $\begin{array}{c}0,1-0,7 \\
0,01-<0,1 \\
<0,01\end{array}$ & $\begin{array}{l}3 \\
2 \\
1\end{array}$ & 3 & $\begin{array}{c}\text { Neksidin } \\
\text { et al. } \\
\text { (2013); KMLH (2004) }\end{array}$ \\
\hline 3. & Fosfat (mg/L) & $\begin{array}{c}0,1-0,2 \\
0,02-1,4 \text { atau } 2,6- \\
3,5 \\
<0,02 \text { atau }>3,5\end{array}$ & $\begin{array}{l}3 \\
2 \\
1\end{array}$ & 3 & $\begin{array}{c}\text { Neksidin } \\
\text { et al. } \\
\text { (2013); KMLH (2004) }\end{array}$ \\
\hline 4. & Kedalaman (m) & $\begin{array}{c}1-10 \\
11-15 \\
<1 \text { atau >15 }\end{array}$ & $\begin{array}{l}3 \\
2 \\
1\end{array}$ & 3 & Radiartha et al. (2005) \\
\hline 5. & $\begin{array}{l}\text { Kecepatan Arus } \\
(\mathrm{m} / \mathrm{dt})\end{array}$ & $\begin{array}{c}0,20-0,30 \\
0,10-0,20 \\
<0,10 \text { atau }>0,40\end{array}$ & $\begin{array}{l}3 \\
2 \\
1\end{array}$ & 3 & Aslan (1991) \\
\hline 6. & MPT (mg/L) & $\begin{array}{l}<25 \\
25-40 \\
>40\end{array}$ & $\begin{array}{l}3 \\
2 \\
1\end{array}$ & 3 & Aslan (1991) \\
\hline 7. & Salinitas & $\begin{array}{c}28-34 \\
18-27 \text { atau } 35-37 \\
<18 \text { atau }>37\end{array}$ & $\begin{array}{l}3 \\
2 \\
1\end{array}$ & 3 & $\begin{array}{c}\text { Neksidin } \\
\text { et al. } \\
\text { (2013); KMLH (2004) }\end{array}$ \\
\hline 8. & Suhu $\left({ }^{\circ} \mathrm{C}\right)$ & $\begin{array}{c}27-30 \\
20-26 \text { atau } 31-36 \\
<20 \text { atau }>36\end{array}$ & $\begin{array}{l}3 \\
2 \\
1\end{array}$ & 1 & $\begin{array}{c}\text { Neksidin } \\
\text { et al. } \\
\text { (2013); KMLH (2004) }\end{array}$ \\
\hline 9. & $\mathrm{pH}$ & $\begin{array}{c}6,5-8,5 \\
5-6,4 \text { atau } 8,6-9 \\
<5 \text { atau }>9\end{array}$ & $\begin{array}{l}3 \\
2 \\
1\end{array}$ & 1 & $\begin{array}{c}\text { Neksidin } \\
\text { et al. } \\
\text { (2013); KMLH (2004) }\end{array}$ \\
\hline 10. & $\mathrm{DO}(\mathrm{mg} / \mathrm{L})$ & $\begin{array}{l}>5 \\
3-5 \\
<3\end{array}$ & $\begin{array}{l}3 \\
2 \\
1\end{array}$ & 1 & $\begin{array}{c}\text { Neksidin } \\
\text { et al. } \\
\text { (2013); KMLH (2004) }\end{array}$ \\
\hline & Total Bobot & & & 24 & \\
\hline
\end{tabular}


Tabel 2. Kriteria Kesesuaian Perairan (Neksidin et al., 2013)

$\begin{array}{cc}\text { Nilai (skor) } & \text { Kriteria } \\ 56-72 & \text { Sesuai } \\ 39-55 & \text { Cukup sesuai } \\ <38 & \text { Tidak sesuai }\end{array}$

Tabel 3. Kualitas Air pada Stasiun Pengamatan

\begin{tabular}{ccccc}
\hline \multirow{2}{*}{ No. } & \multirow{2}{*}{ Parameter } & \multicolumn{3}{c}{ Skor Stasiun Pengamatan } \\
\cline { 3 - 5 } & Kecerahan $(\mathrm{m})$ & 1,11 & $\mathrm{II}$ & $\mathrm{III}$ \\
\hline 1. & Kedalaman (m) & 1,23 & 1,12 & 1,00 \\
2. & Arus $(\mathrm{m} / \mathrm{det})$ & 0,15 & 0,19 & 1,21 \\
3. & Suhu $\left({ }^{\circ} \mathrm{C}\right)$ & 27,72 & 28,16 & 0,23 \\
4. & $\mathrm{pH}$ & 8,21 & 8,46 & 28,72 \\
5. & Salinitas (ppt) & 18,4 & 18,6 & 8,30 \\
6. & Oksigen Terlarut (mg/L) & 8,49 & 8,72 & 20,2 \\
7. & MPT (mg/L) & 19 & 18 & 8,33 \\
8. & Nitrat (mg/L) & 0,46 & 0,50 & 34 \\
9. & Fosfat (mg/L) & 0,08 & 0,13 & 0,37 \\
10. & & & & 0,12 \\
\hline
\end{tabular}

$\mathrm{pH}$ pada stasiun 1,2 dan 3 berturut-turut adalah 8,21; 8,46 dan 8,30. Menurut Abrianti et al. (2017), memiliki pH rata-rata berkisar 8 pada Pantai Bandengan. Hal tersebut sesuai dengan hasil penelitian yang didapat bahwa hasil $\mathrm{pH}$ rata-rata berkisar $8 . \mathrm{pH}$ pada setiap stasiun masuk kedalam kategori sesuai. $\mathrm{pH}$ yang paling tinggi berada pada stasiun 2 dan yang paling rendah pada stasiun 1. Adanya perbedaan $\mathrm{pH}$ pada setiap stasiun dapat disebabkan oleh kedalaman yang berbeda. Nilai $\mathrm{pH}$ mengalami penurunan seiring bertambahnya kedalaman perairan (Sinaga et al., 2016). Secara keseluruhan nilai rata-rata pH sangat sesuai untuk dilakukannya budidaya rumput laut. Nilai perairan pada stasiun Kartini, Prawean dan Bandengan dapat dikatakan tinggi dikarenakan terdapat aktivitas manusia disekitar pantai yang membuang limbah bersifat basa seperti deterjen dan sabun. Menurut Atmanisa et al. (2020), mengatakan bahwa kecenderungan perairan memiliki tingkat keasaman yang tinggi dapat disebabkan oleh masuknya limbah organik dalam jumlah besar.

Salinitas pada stasiun 1,2 dan 3 berturut-turut adalah 18,4; 18,6 dan 20,2 \%o. Konsentrasi salinitas yang paling tinggi berada pada stasiun 3 (Bandengan) dan yang paling terendah yaitu pada stasiun 1 (Kartini). Adanya perbedaan salinitas dan rendahnya salinitas di setiap stasiun bisa disebabkan oleh beberapa faktor, yaitu adanya perbedaan kedalaman dan curah hujan yang tinggi dikarenakan sedang musim hujan pada saat pengambilan data. Menurut Runtuboi et al. (2014), mengatakan bahwa sebaran salinitas laut dipengaruhi oleh suplai air tawar dari sungai, hujan maupun penguapan. Rendahnya salinitas dapat disebabkan oleh adanya pengaruh dari daratan seperti pencampuran dengan air tawar yang terbawa oleh aliran sungai. Pada perairan yang dangkal, air tawar dapat tersebar hingga ke dasar perairan, sehingga salinitas dapat rendah (Sidabutar et al., 2019).

DO pada stasiun 1,2 dan 3 berturut-turut adalah 8,49; 8,72 dan 8,33 mg/L. Nilai DO yang paling tinggi berada pada stasiun 2 dan yang paling rendah pada stasiun 3 . Nilai oksigen terlarut (DO) yang memenuhi syarat untuk hidup dan tumbuh $K$. alvarezii yaitu 4,5-9,8 mg/L (Risnawati et al., 2018). Penelitian yang telah dilakukan oleh Mustofa (2019), mengenai sebaran kandungan oksigen terlarut perairan Pantai sebagai Daya Dukung Usaha Tambak di Kabupaten Jepara mendapatkan hasil kadar DO pada Kecamatan Jepara sebesar 4,7-4,9 mg/L.

Bila dibandingkan dengan hasil kadar DO dalam penelitian ini memiliki nilai yang sangat berbeda. Hal tersebut dapat terjadi karena pengambilan data diambil saat musim hujan sehingga mempengaruhi suhu dan salinitas. Bila suhu dan salinitas semakin rendah maka oksigen terlarut pun semakin bertambah. Hal tersebut juga dipengaruhi oleh kedalaman karena bila semakin 
bertambah kedalaman maka nilai suhu akan menurun, salinitas akan meningkat dan oksigen terlarut akan menurun. Menurut penelitian Sembiring et al. (2012), memiliki nilai DO sebesar 7,9$8,9 \mathrm{mg} / \mathrm{L}$ pada saat pasang dan berkisar $4,5-5,5 \mathrm{mg} / \mathrm{L}$ pada saat surut. Oksigen terlarut baik itu saat pasang ataupun saat surut terlihat semakin ke arah laut maka nilai oksigen terlarut akan semakin besar, ini dikarenakan daerah yang terbuka lebih memudahkan terdifusinya oksigen ke dalam perairan. Hal tersebut dapat menjadi faktor bahwa kadar oksigen terlarut pada perairan Pantai Kartini, Prawean dan Bandengan tergolong tinggi.

MPT pada stasiun 1,2 dan 3 berturut-turut adalah 19; 18 dan $34 \mathrm{mg} / \mathrm{L}$. Pantai Prawean dapat memiliki kadar MPT yang lebih rendah karena terdapat lamun yang dapat menenangkan arus dan gelombang, sehingga padatan tersuspensi di perairan lebih mudah mengendap di dasar perairan (Riniatsih, 2015). Pantai Bandengan memiliki kadar yang lebih tinggi karena pada saat pengambilan data memiliki arus yang lebih tinggi dibandingkan Pantai Kartini dan Prawean yang menyebabkan air menjadi keruh. Menurut Paramitha et al. (2016), arus menyebabkan substrat perairan akan teraduk dan terangkat sehingga membuat perairan menjadi keruh.

Nitrat pada stasiun 1,2 dan 3 berturut-turut adalah 0,46; 0,50 dan 0,37 mg/L. Kadar nitrat paling tinggi berada pada stasiun 2 dan yang paling rendah pada stasiun 3 . Perbedaan kadar nitrat pada setiap stasiun dapat dipengaruhi oleh arus yang berbeda-beda dan pengambilan data yang dilakukan pada musim hujan sehingga kandungan nitrat lebih tinggi terjadi setelah hujan lebat (Setyorini dan Maria, 2019). Arus air yang tidak begitu kuat dapat membuat tidak berjalan sempurna yang menyebabkan stratifikasi horizontal sehingga penyebaran tidak rata (Nugroho et al., 2014). Kadar nitrat di perairan Kecamatan Jepara pada Pantai Prawean dapat lebih tinggi dikarenakan dekat dengan aktivitas industri dan buangan rumah tangga. Pantai Kartini dan Bandengan terdapat aktivitas pariwisata yang memberikan limbah penduduk sekitar. Menurut Hamuna et al. (2018), nitrat diperairan laut dapat bersumber dari aliran sungai akibat aktivitas industri, dan limbah penduduk. Perbedaan nilai rata-rata dapat disebabkan karena adanya pemukiman penduduk yang memungkinkan masuknya nitrat ke dalam perairan (Amri et al., 2018).

Fosfat pada stasiun 1,2 dan 3 berturut-turut adalah 0,08; 0,13 dan 0,12 mg/L. Lebih rendahnya kadar fosfat pada Pantai Kartini dan adanya perbedaan kadar nitrat fosfat pada tiaptiap stasiun dapat dikarenakan oleh arus air yang tidak begitu kuat sehingga tidak berjalan sempurna yang menyebabkan stratifikasi horizontal sehingga penyebaran tidak rata (Nugroho et al., 2014). Namun, kadar pada Pantai Prawean dan Bandengan dapat termasuk baik karena sama halnya dengan nitrat dipengaruhi oleh aktivitas industri dan limbah penduduk.

\section{KESIMPULAN}

Berdasarkan hasil penelitian, maka dapat disimpulkan bahwa kesesuaian lokasi budidaya rumput laut di perairan Kecamatan Jepara berdasarkan kualitas air pada bulan Januari-Februari 2021 menunjukkan bahwa Pantai Kartini (S1), Pantai Prawean (S2) dan Pantai Bandengan (S3) dinyatakan sesuai untuk dijadikan kawasan budidaya rumput laut K.alvarezii.

\section{DAFTAR PUSTAKA}

Abrianti, I., Supriharyono, S. \& Sulardiono, B. 2017. Kelimpahan Epifauna pada Ekosistem Lamun dengan Kedalaman Tertentu di Pantai Bandengan, Jepara. Journal of Marquares, 6(4):376383. DOI: $10.14710 /$ marj.v6i4.21326

Agustang, A., Mulyani, S. \& Indrawati, E. 2019. Analisis Kelayakan Lahan Budidaya Rumput Laut Gracilaria sp. di Tambak Kecamatan Sinjai Utara Kabupaten Sinjai. Journal of Aquactic Environment, 2(1):18-22. DOI : 10.35965/jae.v2i1.332

Amri, K., Muchlizar, M. \& Ma'mun, A. 2018. Variasi Bulanan Salinitas, pH, dan Oksigen Terlarut di perairan Estuari Bengkalis. Majalah IImiah Globë, 20(2):57-66. DOI : 10.24895/MIG.2018.202.645

Aslan, L.M. 1991. Budidaya Rumput Laut. Penerbit Kanisius, Yogyakarta.

Atmanisa, A., Mustarin, A. \& Taufieq, N.A.S. 2020. Analisis Kualitas Air pada Kawasan Budidaya Rumput Laut Eucheuma Cottoni di Kabupaten Jeneponto. Jurnal Pendidikan Teknologi Pertanian, 6(1):11-22. DOI : 10.26858/jptp.v6i1.11275 
Aziz, S.M., Rochaddi, B., Handoyo, G., Muslim, M., Ismanto, A. \& Setyono, H. 2019. Pola Arus dan Sebaran Sedimen di Perairan Jepara. Indonesian Journal of Oceanography, 1(1):1-7.

Dewanto, Y. B., Saifullah, S. \& Hermawan, D. 2015. Evaluasi Kesesuaian Lokasi Pengembangan Budidaya Rumput Laut (Kappaphycus alvarezii) di Desa Lontar, Kecamatan Tirtayasa, Kabupaten Serang. Jurnal Perikanan dan Kelautan, 5(2):49-55.

Dewi, A.P.W.K. \& Ekawaty, R. 2019. Potensi Budidaya Rumput Laut dalam Kaitannya dengan Dampak Perkembangan Pariwisata di Perairan Pantai Kutuh, Badung, Bali. Journal of Marine and Aquatic Science, 5(1): 94-99. DOI : 10.24843/jmas.2019.v05.i01.p12

Erbabley, N.Y.G.F. \& Kelabora, D.M. 2018. Identifikasi Bakteri Rumput Laut Kappaphycus alvarezii Berdasarkan Musim Tanam di Perairan Maluku Tenggara. Jurnal Akuatika Indonesia, 3 (1):1925. DOI : 10.24198/jaki.v3i1.23398

Fikri, M.,Rejeki, S. \& Widowati, L.L. 2015. Produksi dan Kualitas Rumput Laut (Eucheuma cottonii) dengan Kedalaman Berbeda di Perairan Bulu Kabupaten Jepara. Journal of Aquaculture Management and Technology, 4(2):67-74.

Hamuna, B., Tanjung, R.H.R., Suwito, S. \& Maury, H.K. 2018. Konsentrasi Amoniak, Nitrat dan Fosfat di Perairan Distrik Depapre, Kabupaten Jayapura. EnviroScienteae, 14(1):8-15. DOI : 10.20527/es.v14i1. 4887

Kementrian Lingkungan Hidup. 2004. Keputusan Kementrian Lingkungan Hidup No. 51. Kementrian Lingkungan Hidup, Jakarta, $10 \mathrm{hlm}$.

Mustofa, A. 2019. Sebaran Kandungan Oksigen Terlarut Perairan Pantai sebagai Daya Dukung Usaha Tambak di Kabupaten Jepara. Jurnal DISPROTEK., 10(2): 95-100. DOI : 10.34001/jdpt.v10i2.1076

Neksidin, N., Pangerang, U.K. \& Emiyarti, E. 2013. Studi Kualitas Air untuk Budidaya Rumput Laut (Kappaphycus alvarezii) di Perairan Teluk Kolono Kabupaten Konawe Selatan. Jurnal Mina Laut Indonesia, 3(3):1-9.

Nugraha, W.A., Rochaddi, B. \& Rifai, A., 2015. Studi Batimetri dan Berkurangnya Daratan di Wilayah Pesisir Tugu Semarang. Jurnal Oseanografi, 4(2):442-450.

Nugroho, A. S., Tanjung, S.D. \& Hendrato, B. 2014. Distribusi Serta Kandungan Nitrat Fosfat di Perairan Danau Rawa Pening. Jurnal IImiah Biologi, 3(1):27-41. DOI : 10.26877/bioma.v3i1,20April.648

Nuning, M.N., 2015. Analisis Kesesuaian Perairan Ketapang, Lampung Selatan sebagai Lahan Budidaya Rumput Laut Kappaphycus alvarezii. Maspari Journal, 7(2):91-100. DOI : 10.36706/maspari.v7i2.2487

Paramitha, V.K., Yusuf, M. \& Maslukah, L. 2016. Sebaran Muatan Padatan Tersuspensi (MPT) di Perairan Karangsong, Kabupaten Indramayu. Jurnal Oseanografi, 5(2):293-300.

Patty, S. I., Huwae, R. \& Kainama, F. 2020. Variasi Musiman Suhu, Salinitas dan Kekeruhan Air Laut di Perairan Selat Lembeh, Sulawesi Utara. Jurnal IImiah Platax, 8(1):110-117.

Radiartha, I.N., Saputra, A. \& Johan, O. 2005. Pemetaan Kelayakan Lahan untuk Pengembangan Usaha Budidaya Laut dengan Aplikasi Inderaja dan Sistem Informasi Geografis di Perairan Lemito, Propinsi Gorontalo. Jurnal Penelitian Perikanan Indonesia, 11(1):1-13. DOI : 10.15578/jpbkp.v10i3.380

Riniatsih, I. 2015. Distribusi Muatan Padatan Tersuspensi (MPT) di Padang Lamun di Perairan Teluk Awur dan Pantai Prawean Jepara. Jurnal Kelautan Tropis, 18(3):121-126. DOI : 10.14710/jkt.v18i3.523

Risnawati, R., Kasim, M., \& Haslianti, H. 2018. Studi Kualitas Air dengan Pertumbuhan Rumput Laut (Kappaphycus alvarezii) pada Rakit Jaring Apung di Perairan Pantai Lakeba Kota BauBau Sulawesi Tenggara. Jurnal Manajemen Sumber Daya Perairan, 4(2):155-164.

Runtuboi, D., Paulungan, Y.P. \& Gunaedi, T. 2014. Studi Kesesuaian Lahan Budidaya Rumput laut Berdasarkan Parameter Biofisik Perairan di Yensawai Distrik Batanta Utara Kabupaten Raja Ampat. Jurnal Biologi Papua., 6(1):31-37.

Sembiring, S.M.R., Melki, M. \& Agustriani, F. 2012. Kualitas Perairan Muara Sungsang ditinjau dari Konsentrasi Bahan Organik pada Kondisi Pasang Surut. Maspari Journal, 4(2):238-247.

Setyorini, H.B., \& Maria, E., 2019. Kandungan Nitrat dan Fosfat di Pantai Jungwok, Kabupaten Gunungkidul, Yogyakarta. Jurnal Sumberdaya Perairan, 13(1):87-93. DOI : 10.33019/akuatik.v13i1. 1201 
Sidabutar, E.A., Sartimbul, A. \& Handayani, M. 2019. Distribusi Suhu, Salinitas dan Oksigen Terlarut terhadap Kedalaman di Perairan Teluk Prigi Kabupaten Trenggalek. Journal of Fisheries and Marine Research, 3(1):46-52. DOI : 10.21776/ub.jfmr.2019.003.01.6

Sinaga, E.L.R., Muhtadi, A. \& Bakti, D. 2016. Profil Suhu, Oksigen Terlarut dan pH Secara Vertikal Selama 24 Jam di Danau Kelapa Gading Kabupaten Asahan Sumatera Utara. Omni-Akuatika, 12(2):114-124. DOI : 10.20884/1.oa.2016.12.2.107

Yusuf, M., Handoyo, G., Muslim, M., Wulandari, S.Y. \& Setiyono, H. 2012. Karakteristik Pola Arus dalam Kaitannya dengan Kondisi Kualitas Perairan dan Kelimpahan Fitoplankton di Perairan Taman Nasional Laut Karimun Jawa. Buletin Oseanografi Marina, 1(1):63-74. DOI: 10.14710/buloma.v1i5.6918 